\title{
フレキシブルシルク電極（繊維電極）
}

\section{Flexible Silk Electrode: Fiber Electrode}

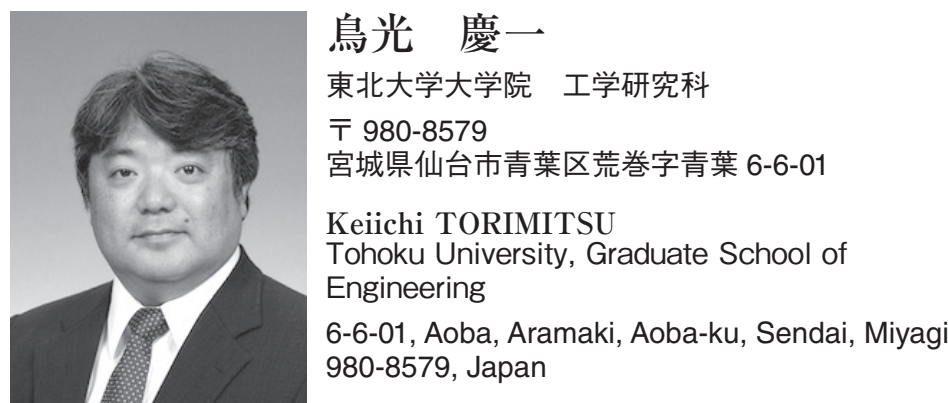

論文要旨：バイタル等の生体信号を取得する上で電極の生体適合性はもちろんながら, その肌感触や風合 いは極めて重要である。計測していることを意識させないさりげなさは, 計測によるストレスを軽減させる。 シルクなどの繊維素材は，この様な点で優れており，導電性化することでストレスの少ないフレキシブルな 電極としてバイタル計測に最適であると考える。本稿では, この緎維電極についてその技術と可能性につい て紹介する。

Abstract: Flexibility and texture of the electrode could be very important features in vital measurement. Fibers, such as silk are ideal for reducing stress from long-term measurement. We modified fibers with conductive polymers make them conductive. Here we introduce our conductive fibers as fiber electrode for vital assessment.

Key words: silk, fiber electrode, PEDOT, brain, vital-conditions

\section{1 はじめに}

本年は，COVID19によりこれまでに我々が体験した ことのない様な状況で推移している。これまで当たり前 だった対面での打ち合わせや会議などがオンラインに変 わり，才フィスから自宅への勤務形態の変更や出張の取 りやめが日常に変わった。この様に外出する機会が減っ ている中，精神面を含めた自身の健康状態をいかに維持 するかが極めて重要な課題となっている。気軽に健康状 態を知ることができるウェアラブル機器の重要性はます ます高まっていると言える。

生体情報の取得は，技術の進展により手軽に収集でき る様になってきた。携帯性の向上については，格段に向 上した。腕時計型のデバイスでは, 小型・軽量化が図ら れ，心拍などの他血中酸素濃度まで計測可能となり，運 動量を含めた評価ができる様になってきている。シャツ 用の着用型のものも計測感度やソフト面での向上が見ら れている。

連絡者：鳥光 慶一

E-mail : torimitu@biomems.mech.tohoku.ac.jp
一方で，短期間の運動などでの着用の場合には問題な いものの, 長期間の着用に伴い生じる掻痒感などの生体 反応については，未だ良い解決方法が見出されていな い。これは, 肌に対する高い密着性が必要であることや, 水分やジェルなど肌との接触抵抗を減らすための工夫が 必要であるためであり，蒸れによる炎症や金属アレル ギーなどの拒否反応が避けられないことによる。我々が 怪我をした時に使用する粘着性のパッドや絆創膏を使用 した際に生じる問題と同様の問題である。

本研究で用いたシルクは古くから衣料材料として用い られてきただけでなく，生体適合性が高いことが知られ ており，外科手術の際の手術糸として使用されている。 セリシンおよびフィブロインといったタンパク質が主成 分のため, 体内に留置しても分解されるというメリットも ある。シルクはそのしなやかな肌ざわりと吸湿性の高さ から肌に触れても蒸れや掻痒感を感じにくい。まれにア レルギーを示す方もいるが，概して炎症反応を生じにく い素材である。我々はこの様な素材に対し, 導電性高分 子を重合させることで導電性シルクを開発してきた ${ }^{1-5)}$ 。

シルク導電性化のきっかけは，それまで進めていた脳 
研究におけるフレキシブルな電極の必要性からである。 記憶学習など脳機能の解明を図る上で, 脳を構成する神 経細胞の活動を計測する必要があったが，脳は非常にデ リケートな組織であり，わずかな衝撃でも傷つきやす い。計測においても十分な注意が必要である。

これまでの主な計測方法は, ガラス微小電極や金属電 極を用いて細胞近傍や細胞に刺入することで膜電位など の電気的特性を評価する方法や，神経細胞を取り出した 後人工的環境下で微小アレイ電極 (MEA, multi electrode array）上に培養し電気的活動を計測する方法が 主であった ${ }^{6-9)}$ 。MEA は非破壊的に細胞の電気特性を 計測できる点で優れているものの，ガラス基板がベース となっており，微細加工したITO (Indium Tin Oxide) 電極がアレイ化されたものである。したがってほとんど 変形しない素材であることから，脳組織など柔らかく損 傷しやすいものには不向きである。ガラス基板をポリイ ミドなどの高分子フィルムに置き換えることでフレキシ ビリティを持たせたものも作製したが，フィルムの剛性 や表面の微細な凹凸によっても組織がダメージを受ける ため，適当ではなかった。

そこで, 脳表面の複雑な構造や組織にダメージを与え にくい基板素材として布状の材料に着目し，シルクを基 材とする電極作製に至った。本来絶縁物質のシルクに導 電性を持たせるために導電性の素材を導入する必要があ り, 前出の MEA 電極において ITOのインピーダンス を下げ，生体適合性を高める目的で使用していた導電性 高分子の PEDOT (poly (3,4-ethylenedioxythiophene)) 化合物を修飾することにした ${ }^{10,11)}$ 。PEDOTは，それま でのポリピロールなどの導電性高分子 ${ }^{12,13)}$ に代わる材 料として注目され，当時我々はリンショーピン大学と協 力して神経活動検出への応用を検討していた。結果とし て神経細胞に対する適合性が高く，導電性も良いことが 明らかになっていたことから，この物質をシルクと組み 合わせることに取り組んだ。作製した導電性シルクは, 素材本来のしなやかさ, 肌触りの良さなどはそのままで, 素材の質感を損なわずに導電性化することに成功した。 現在では, シルクの他，和紙や合成繊維についても同様 の手法で導電性化しており, これらをまとめて『繊維電 極』と呼んでいる。パーキンソン病などの治療に向けた 刺入用のものや, 筋電 · 心電などの体表面からの電気信 号を計測するもの, 非接触で体の動きやバイタルを計測 するものなどの他，新たな特性を有する素材として様々 な用途に対応した電極を開発している。本稿では, この 繊維電極について紹介する。

\section{2 フレキシブルシルク電極（繊維電極）}

フレキシブルシルク電極は, 前出の様にシルクに対し 導電性高分子を修飾することで電気を通す素材に変化さ せたものである。Fig. 1 にフレキシブルシルク電極の作 製法について示す ${ }^{1-5)}$ 。本稿では対象繊維に導電性高分 子としてPEDOT 化合物を重合して修飾している。重 合には，電解重合，化学重合などの重合法があるが，後 者の方が修飾後の抵抗值が低いため, ここでは化学重合 による修飾を行っている。PEDOT 化合物にバインダー を加えることで, 塗るだけで済むコーティング法でも導 電性化は可能であるが，剥離等各々メリット・デメリッ トがある。

基材としてのシルクは，先に述べた様にセリシンと フィブロインという 2 種類のタンパク質から構成されて いる。フィブロインの周りをセリシンが取り囲んだ構造 となっており, 我々が知る素材としてのシルクは, 精練 過程でこのセリシンを減少または除去したものである。 導電性高分子は主としてセリシンと結合しており, これ により導電性化合物が剥がれにくい状態になっていると 考えられる。この導電性化の特徵的なことは, 素材の特 性がほとんど失われることはなく，肌触りなどの質感が そのままであることである。その特徵は, 数回の洗濯を してもほとんど変化しない。電気特性についても同様で はあるものの, もともとシルク自身が素材として劣化し やすい傾向にあるので, 洗濯による繰り返し使用には限 界がある。

この様な質感や肌触りは主観によるところが大きく， 定性的な表現であるため, 客観的に評価することが困難 である。そこで, 質感や肌触りを客観的に評価するため, 摩擦測定や濡れ性などの物理的パラメータを計測導入す

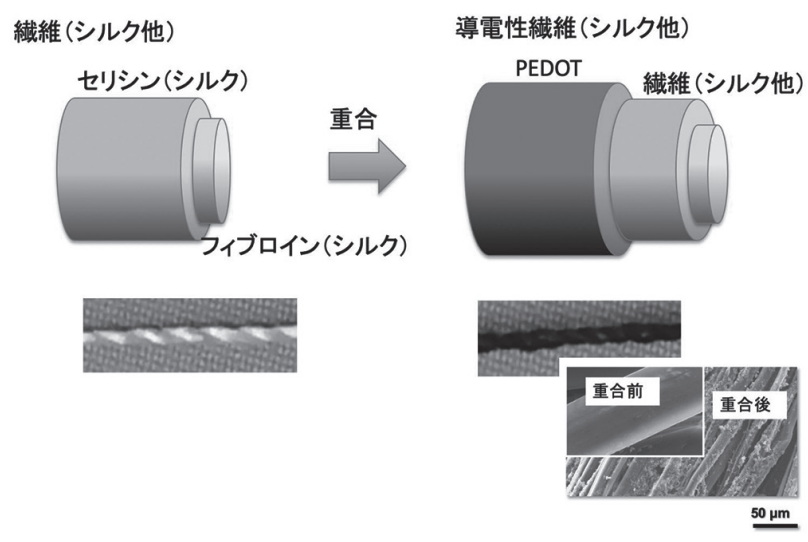

Fig. 1 繊維の導電性化 
ることで評価する試みを行った。摩擦感テスター (KESSE）は, 摩擦係数, 摩擦係数の変動のデータから, 触っ た時の滑らかな感じを定量的に評価することが可能であ る。この計測により，他に比べシルク素材の優れた特性 が明らかとなり，その特性が導電性化処理前後でほとん ど変化しないことも明らかとなった。

また，触覚について圧電素子を用いた計測により評価 する触覚感性計測 $3 ， 14$, 15) を導入し，濡れ性などの感性 評価を行ったところ, こちらも導電性化処理前後でほと んど変化していなかった。これらの計測により，定量的 にもシルク本来の素材感をそのままに導電性化が可能で あることがわかった。

この導電性化はシルクだけにとどまらず，他の素材に ついても可能である。我々は, 環境負荷が低い天然素材 を中心に研究を進めており，和紙もその一つである。和 紙は，単に紙としてだけでなく，紙から糸，さらに糸か ら布にした和紙布を導電性化し研究に用いている。合成 纎維でも修飾可能であり, 用いる繊維により各々の特徵 が異なるため,「纎維電極」としてその素材特性を活か した活用方法を各々展開中である。

\section{3 応用例}

ここでは, 繊維電極のうち, フレキシブルシルク電極 （以後, シルク電極と呼ぶ）の使用例を中心に紹介する。 シルク電極には，絹糸をベースにした糸状の電極と，絹 布をべースにした布状電極がある。糸電極は, 細いため 数百〜数 $\mathrm{k} \Omega / \mathrm{cm}$ と抵抗值がやや高めであるものの，局 所的な刺激や変化の測定に有利である。また, 外科留置
する際の結紮等利点がある。

\section{$3 \cdot 1$ 糸状電極実験例}

Fig. 2 に, ニワトリ肧の脳神経活動および筇肉内部の 電位計測の活用例を示す。シルク電極を生体組織で使用 する場合には, 通常の縫製用の細糸と異なり, やや硬め の手術用の糸を使用する。脳組織は非常に柔らかいため, インサーターがなくても糸だけで刺入することが可能で ある。本例では, 2 本の糸状電極（約 $1 \mathrm{k} \Omega / \mathrm{cm}$ ）を利用 し，片方を基準電極，もう片方を測定用電極とした。麻 酔下での実験で，主に $\gamma$ 波を指標とした脳の各部におけ る神経活動が計測できている。活動は生育と共に盛んに なることや, 視覚刺激に誘発されて生じる誘発電位も検 出可能であるなど感度の高い計測が実現できている。

一方, シルク電極は, 電極刺入による細胞組織の破壊 を防ぐため, ECoG（Electrocorticogram，皮質脳波） の様な電極刺入を必要としない非破壊計測 ${ }^{3-5)} に も$ 対応 できることがわかった。図では，糸を重ねた交点近傍の ミリメートル範囲の神経活動を示した。導電性化してい ない絶縁状態の生地に導電性の糸状電極を $1-2 \mathrm{~mm}$ 程 度 4 力所に露出させ, 硬膜下の脳表面に接触させた状態 での計測結果である。この結果より数ミリ程度の糸状電 極で脳波の計測が可能であること，そして縫うだけで簡 便に多点計測系の構築を実現できることが明らかとなっ た。

次に，筋肉活動についての計測結果を示す（Fig. 3)。 縫合の様に傷口を塞ぐ要領で筋肉に糸状電極を通すこと ができるため，任意の場所に電極を留置し，筋肉活動を 計測することが可能である。金属電極ではないため, 動 (a)

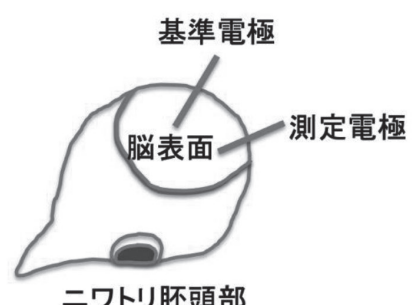

(b)

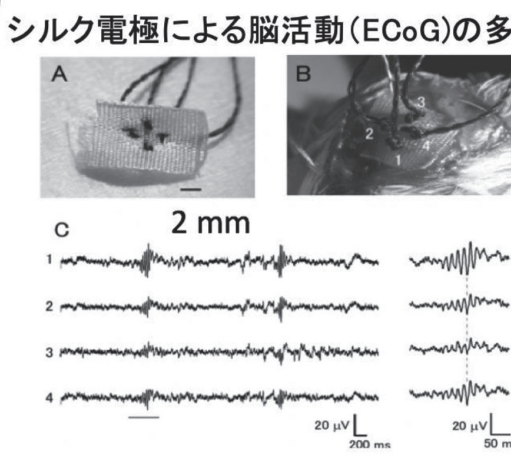

視覚刺激に対する応答 $(\gamma$ 波)

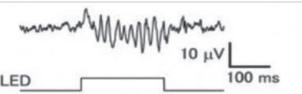

局所刺激に対する脳の 応答(誘発電位)

Stim

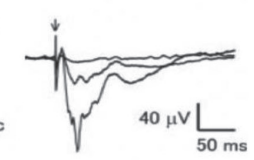

\section{電極の設置状態}

\section{シルク多点電極からのECoG記録}

Fig. 2 シルク電極を用いた脳の活動計測（ref.5 より） 

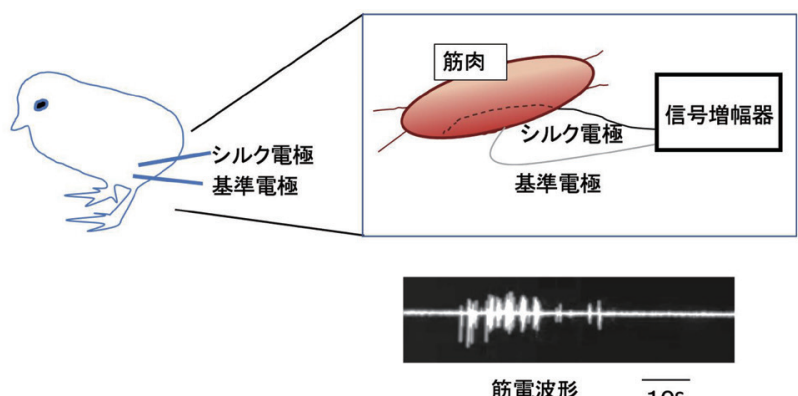

Fig. 3 シルク電極による筋肉活動計測
きを伴う運動時においても痛みをほとんど感じることな く, 筋内電位が計測できる特徵を有している。筋肉の損 傷および回復過程や電気刺激による活動誘導などの実験 に有効的な手法となりうると考えている。

\section{$3 \cdot 2$ 布状電極実験例}

布状の電極には大別して 2 つの使い方がある。

一つは，接触測定であり，肌に触れることで心電や筋 電などのバイタル信号を取得する。既存の金属電極やゲ ルまたはゴム状の電極などに比べ皮膚との接触性に優れ

\section{(a)心電計測}

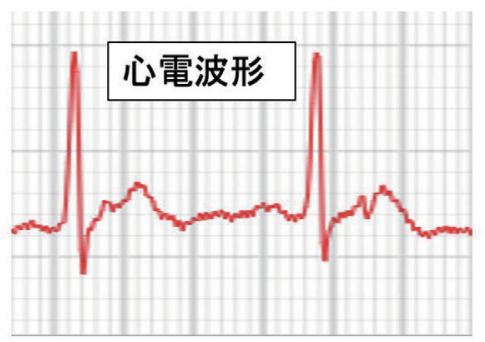

\section{無線心電計}

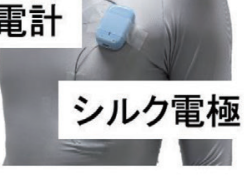

\section{(b)筋電計測}
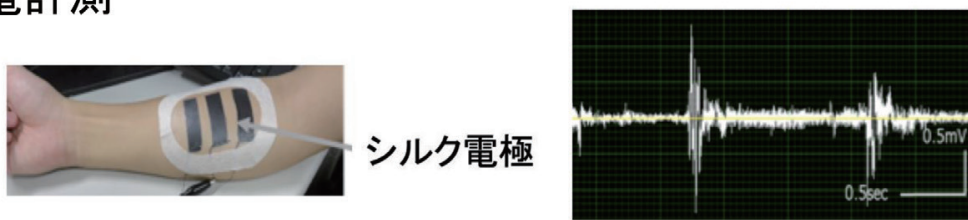

筋電波形

Fig. 4 シルク電極による心電・筋電計測
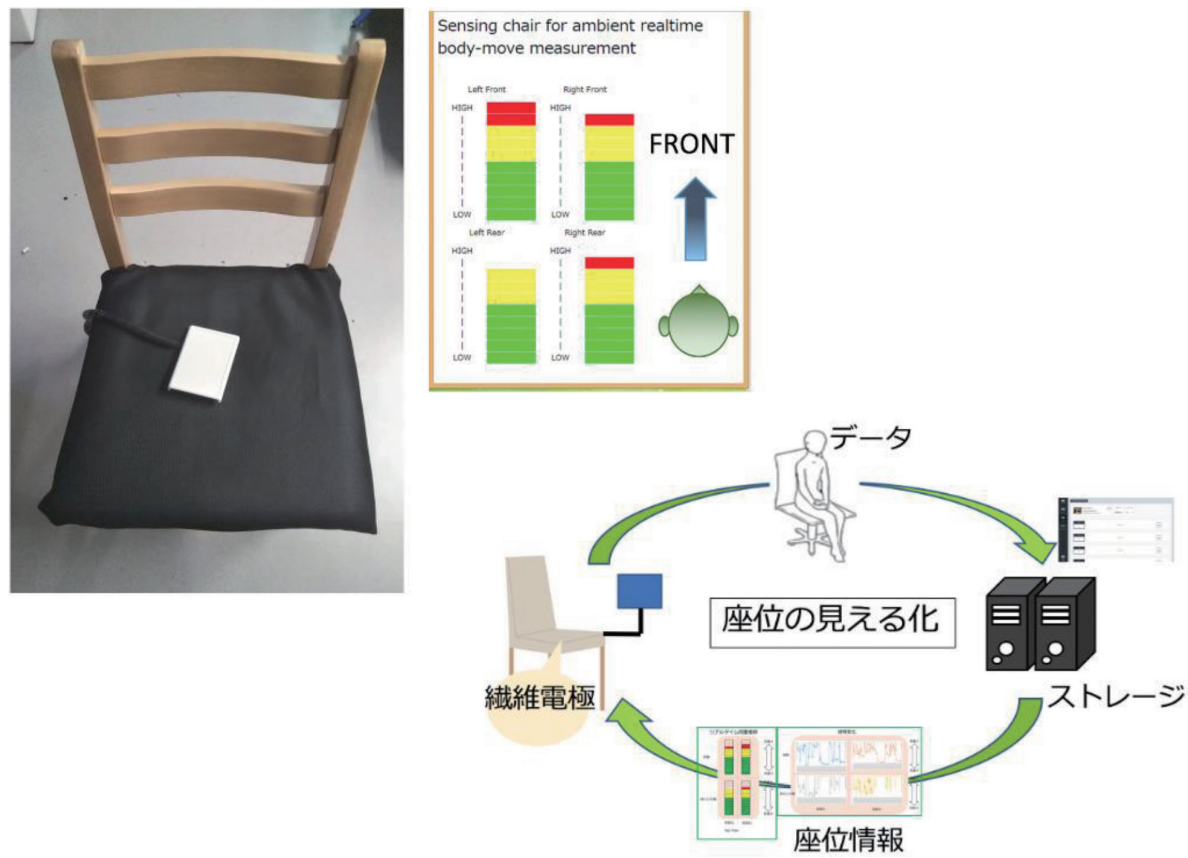

Fig. 5 繊維電極による座位情報の取得と評価 
ているため, ジェル等の使用がなくても軽く接触させる, すなわち特に強い締め付けを必要としない肌着やシャツ などに使用することで，心電波形を検出可能である。

Fig. $4 \mathrm{a}$ には胸部にシルク電極を有するシャツを着用し た際に取得した心電波形を示した。比較的 $\mathrm{S} / \mathrm{N}$ よくシ グナルが取得できていることがわかる。また，前腕部に リボン状のシルク電極を貼ることで，筋肉の動きに伴う 筋電位変化を計測した結果を示した (Fig. 4b)。電極自 体の感度が高いため, 電極の大きさを小さくすることで 検出精度の向上につながり，アレイ化との併用により， より細かい動きの検出とフィードバックが可能となって きた。この筋電情報を利用することで筋活動に連動させ た制御手法の開発を進め, ロボットや義手義足, 電動車 椅子などへの展開を行っている。また，テキスタイルへ の適用を通して，より自然なウェアラブル計測手法とし て，ヘルスケア分野でのバイタル評価を目指している。

もう一つは非接触測定である。

これまでの電極は肌との接触を通して電気情報を取得 するものであったが，ここでは，肌に接触することなく， 布状電極自身をセンサーとして活用することで，荷重や 体動を計測評価することに取り組んでいる。

この方法では，半導体センサーを必要としないため配 線を含めた金属フリーでのセンシングが可能である。も ちろん増幅系や通信系などの電子回路は必要であるが, センシング部は全くこれらの部品を必要としない。直接 肌に触れることがないため, 心電などの電気的応答を計 測評価するには不向きである。しかしながら，荷重や体 の動きに伴う変化を計測できるため, 呼吸や心拍などの バイタル評価の際にも, 何かに触られている, あるいは 触れている感覚がないため，ストレスフリーであること が大きな特徴である。
我々は普段, 監視カメラや赤外線, マイクロ波などを 通して様々な情報を取得されているが，カメラが目に入 ると常に監視されていることを意識して緊張するもので ある。たとえ監視されていても，監視されていることを 気づかずにさりげなく計測できれば少しは気が楽であ る。この非接触測定はこの様なさりげなさを兼ね備えた 計測法であると言える。

詳しい原理はここでは省くが，この原理を応用した着 席時にかかる体の荷重分布計測例を示す（Fig. 5)。左右 の臀部と脚部を示す 4 カ所のカラーバーは各部にかかる 荷重の度合いを示したもので, 赤くなるほど荷重がか かっている状態である。100 ms 毎の計測データをリア ルタイム表示している。これにより骨盤の前後左右傾状 態を推定することができる。適正な状態を維持すること で未病につなげるための指標を提供することを目標にし て研究を進めている。

\section{$3 \cdot 3$ 新しい素材として}

当初生体信号の検出を目的とした電極としてスタート したシルク電極であるが, 現在は様々な用途として活用 されている。特にここで使用している導電性高分子は, これまでに様々な活用法が検討されており，生理学的に も興味深い利用法としては, 次にあげるイオンポンプと しての活用法である。

カロリンスカ医科研およびリンショーピン大学では神 経伝達物質を供給するためのイオンポンプ ${ }^{16)}$ としてこ の導電性高分子を活用し，突発性難聴などのメカニズム 解明を目指している。イオンは液溜めから供給される。 液溜めに電場を印加することでイオンの供給量を制御す る仕組みであり，この方法でカリウムイオンを供給し脱 分極を生じさせ細胞を興奮状態にさせる。また, 神経伝 達物質を供給するための補給源としての検討も行ってい
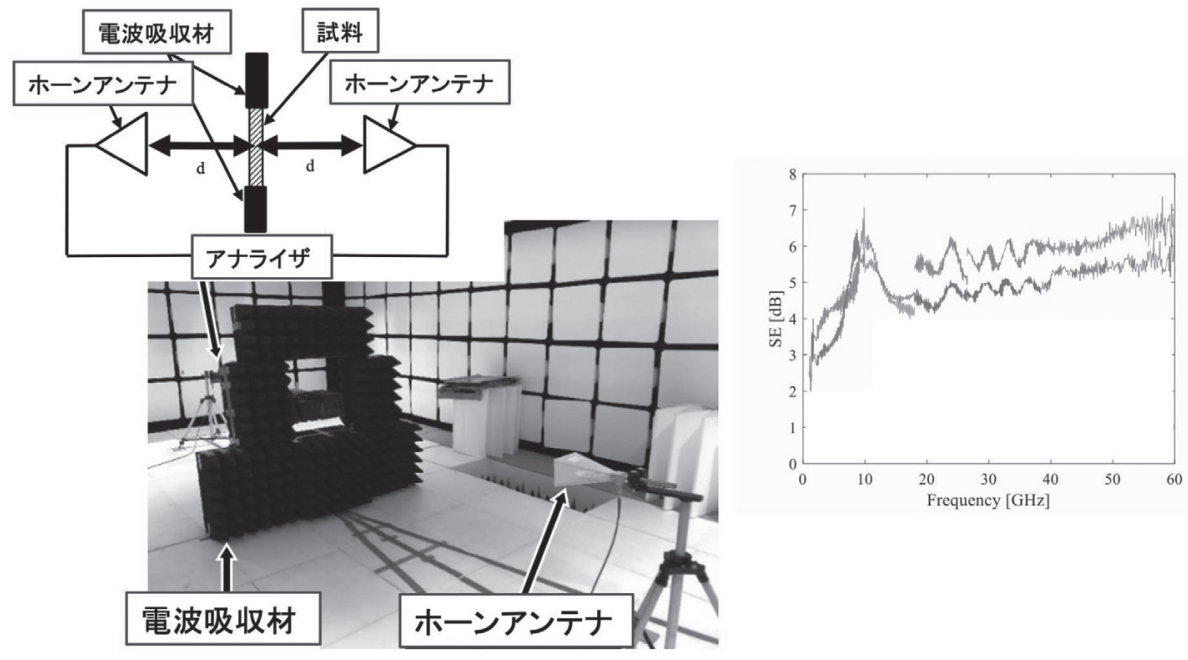

Fig. 6 繊維電極による電波吸収（ref 19 より） 
る。その他にも電気化学トランジス夕 ${ }^{17)}$ や人工シナプ スへの活用 ${ }^{4,18)}$ ，高い生体適合性を活用した修飾などが 提案されている。

また今回は取り上げないが, 我々はこれまでの研究で, 繊維電極が前出の生体電気信号の検出用途の他に発電, あるいは非接触センシング機能, 電波遮蔽に応用可能で あることがわかってきた。特に電波遮蔽においては，電 波暗室での計測結果から，1-60 GHzの範囲でほぼフ ラットに減衰特性を有することが明らかとなってきた。 マイクロ波領域においても 6 $8 \mathrm{db} /$ 枚程度の減衰効果 があり，遮蔽効果は厚さをコントロールすることで調節 可能であることから，遮蔽効果のあるテキスタイルをは じめとする様々な用途が期待できると考えている ${ }^{19)}$ (Fig. 6)。PEDOT 化合物は適用範囲も広く，これから もまだ様々な応用分野において活用されていくものと期 待される。

\section{4 おわりに}

本稿では，シルクを中心とした繊維について，その導 電性化による繊維電極の可能性を紹介してきた。繊維電 極は，基材である繊維の風合いや肌触りを変えることな く導電性を保持できるだけでなく，その高い生体適合性 から応用範囲の広い分野への活用が期待できる。また, その作製工程のシンプルさと低環境負荷の特徵から経済 性，環境特性の点で優れている。電極自身がセンサーに なり, 計測用の半導体センサーを必要としないという緎 維電極の特徵から, 繊維生産に関わる人・会社が簡単に ウェアラブルセンシング分野に参入できるといった産業 障壁の低さにより，今までにない異分野領域における業 態拡大の実現につながるものと期待される。

一方で，これまでの伝統的な素材であるシルクや和紙 などの新しい活用法を提案することで，失われつつある 纎維に関わる重要なノウハウ・技術を維持し, 異分野の 新しい技術を融合することで新たな発展・業界の活性化 につながればと考えている。

また，これまでの接触計測が中心であったバイタル計 測分野において, 非接触計測が可能な繊維電極の特性は, 今後の在宅・遠隔医療を含めたへルスケア分野における 健康状態の把握をさりげなく，かつ容易に行えるだけで なく，自分の健康状態を常に把握し，異常を早期に察知 することで未病につなげるための重要なツールの一つと して様々なケースで活用されることを期待している。

\section{文 献}

1) S. Tsukada, H. Nakashima, and K. Torimitsu, PLoS ONE, 7, e33689 (2012).
2) K. Torimitsu, H. Takahashi, T. Sonobe, Y. Furukawa, PEDOT-PSS modified silk electrode for neural activity measurement, E. J. of Neurology, 21, 190 (2014)

3) K. Torimitsu, H. Takahashi, T. Sonobe, Y. Furukawa, Activity measurement using conductive polymer flexible electrode, Proc. ISBS 2014 St Petersburg_Russia, Stress, Brain and Behavior, 1, 23 (2014).

4）鳥光慶一, 医療に向けたフレキシブルウェットデバイ ス, Nature Interface, 61, 12-13 (2013). (K. Torimitsu, Nature Interface, No. 61, 12-13 (2013))

5) S. Watanabe, H. Takahashi and K. Torimitsu, Electroconductive polymer-coated silk fiber electrodes for neural recording and stimulation in vivo, Jpn. J. Appl. Phys., 56, 037001 (2017).

6) H. P. C. Robinson, M. Kawahara, Y. Jimbo, K. Torimitsu, Y. Kuroda, A. Kawana, Periodic synchronized bursting and intracellular calcium transients elicited by low magnesium in cultured cortical neurons, $J$. of Neurophysiol., 70, 1606-1616 (1993).

7) Y. Jimbo, N. Kasai, K. Torimitsu, T. Tateno, H. P. C. Robinson, MEA-based multi-site stimulation system, IEEE Trans. Biomed. Eng., 50, 241-248 (2003).

8) T. Nyberg, A. Shimada, K. Torimitsu, Ion conducting polymer microelectrodes for interfacing with neural networks, J. Neurosci. Methods, 160, 16-25 (2007).

9) Y. Furukawa, A. Shimada, K. Kato, H. Iwata, K. Torimitsu, Monitoring neural stem cell differentiation using PEDOT-PSS based MEA, BBA Gen. Sub., 1830, 4329-4333 (2013).

10) G. Heywang \& F. Jonas, Poly (alkylenedioxythiophene)s -new, very stable conducting polymers. Adv Mater., 4, 116-118 (1992).

11) S. Ghosh, O. Inganas, Conducting polymer hydrogels as 3D electrodes: applications for supercapacitors. Adv Mater., 11, 1214-1218 (1999)

12) G. Lillie, P. Payne, and P. Vadgama, Electrochemical impedance spectroscopy as a platform. for reagentless bioaffinity sensing. Sensors and Actuators B, 78, 249256 (2001).

13) X. Liu, Gilmore, K. J., Moulton, S. E., and Wallace, G. G., Electrical stimulation promotes nerve cell differentiation on polypyrrole/poly (2-methoxy-5 aniline sulfonic acid) composites, J. Neural Eng., 6, 065002 (2009).

14) M. Tanaka, S. Chonan, Z. Jiang, H. Nakajima, Measurement and valuation of touch sensation (Tactile perception of forefinger compared with PVDF sensor output), Trans. of the Jap. Soc. of Mech. Eng., C, 65, 970976 (1999).

15) M. Tanaka, Y. Tanaka, S. Chonan, Measurement and evaluation of tactile sensations using a PVDF sensor, $J$. of Intelligent. Mat. Sys. and Struct., 19, 35-42 (2008).

16) D. T. Simon, S. Kurup, K. C. Larsson, R. Hori, K. Tybrandt, M. Goiny, E. W. H. Jager, M. Berggren, B. Canlon \& A. Richter-Dahlfors, Organic electronics for precise delivery of neurotransmitters to modulate mammalian sensory function, Nature Materials 8, 742- 
746 (2009).

17) C. Müller, M. Hamedi, R. Karlsson, R. Jansson, R. Marcilla, et al., Woven electrochemical transistors on silk fibers. Adv Mater., 23, 898-901 (2011).

18) K. Torimitsu, K. Miura, Conductive polymer-based fiber-electrode for bioactivity measurement, SFN2019,
Chicago USA, 10.19-23 (2019).

19) K. Edamatsu, M. Motoyoshi, N. Suematsu, K. Miura, K. Torimitsu, Electromagnetic shielding of conductive polymer combined fabric, Proc. $12^{\text {th }}$ Global Symposium on Millimeter-Waves (GSMM2019), 44-46 (2019). 